\title{
New Natural Products from Siphoneugena densiflora Berg (Myrtaceae) and their Chemotaxonomic Significance
}

\author{
Margareth B. C. Gallo, ${ }^{*}$ Fernando C. da Silva, Paulo C. Vieira, João B. Fernandes and \\ Maria Fátima das G. F. da Silva
}

Departamento de Química, Universidade Federal de São Carlos, CP 676, 13560-970 São Carlos - SP, Brazil

\begin{abstract}
Siphoneugena Berg (Myrtaceae) é um pequeno gênero eugenióide segregado de Eugenia por Berg. A investigação fitoquímica de Siphoneugena densiflora foi realizada com o objetivo de se descobrir metabólitos secundários que possam ser considerados marcadores quimiotaxonômicos e auxiliar na distinção entre os dois gêneros. Cinco taninos hidrolisáveis inéditos foram isolados do extrato metanólico da casca da raiz e caracterizados como $4-O-\alpha-\mathrm{L}-$ 2"- $O$ - e seu isômero 4- $O-\alpha$-L-3"- $O$-acetilramnopiranosídeo do ácido elágico, siphoneugenina, constituído por uma nova aglicona de estrutura dibenzo-1,4-dioxínica, 4- $O-\beta$-D-6"- e 4- $O-\beta$-D3",6"-di- $O$-acetilglucopiranosídeo do ácido 3,4'-di- $O$-metilelágico, juntamente com o 4-O- $\alpha$ L-4"- $O$-acetilramnopiranosídeo do ácido elágico, eschweilenol $\mathrm{C}$, sitosterol, daucosterol, ramnose, casuarinina, castalagina e ácidos elágico, gálico e siríngico. Do extrato metanólico das folhas, além dos compostos conhecidos como a quercetina, quercitrina, guiajaverina, reinoutrina, chebulosídeo II, ácidos terminólico, madecássico e asiático, lupeol, $\alpha$ - e $\beta$-amirina, foi isolado um novo triterpeno pentacíclico nomeado como $2 \alpha, 3 \beta, 6 \beta$-triidroxiolean-12-en-28ato de $\beta$-D-glucopiranosila. Todas as substâncias foram identificadas através da análise dos dados espectrais e químicos obtidos, além da comparação com dados relatados na literatura.
\end{abstract}

Siphoneugena Berg (Myrtaceae) is a small eugenioid genus segregated from Eugenia by Berg. The phytochemical survey of Siphoneugena densiflora was carried out in order to find secondary metabolites which may be considered as chemotaxonomic characters and help to distinguish between the two genera. Five novel hydrolysable tannins were isolated from the methanolic extract of root bark and were characterized as ellagic acid 4-O- $\alpha$-L-2"-O- and its isomer $4-O-\alpha-\mathrm{L}-3$ "- $O$-acetylrhamnopyranoside, siphoneugenin, that supports a new aglycone with a dibenzo-1,4-dioxin structure, 3,4'-di- $O$-methylellagic acid 4- $O-\beta$-D-6"' $O$ - and 4- $O-\beta$ D-3",6"-diacetylglucopyranoside, accompanied by ellagic acid 4- $O-\alpha$-L-4"- $O$-acetylrhamnopyranoside, eschweilenol $\mathrm{C}$, sitosterol, daucosterol, rhamnose, casuarinin, castalagin, ellagic, gallic and syringic acids. From methanolic extract of leaves, in addition to the well known compounds quercetin, quercitrin, guiajaverin, reynoutrin, chebuloside II, terminolic, madecassic and asiatic acids, lupeol, $\alpha$ - and $\beta$-amyrin, a new pentacyclic triterpene was isolated and named as $\beta$-D-glucopyranosyl- $2 \alpha, 3 \beta, 6 \beta$-trihydroxyolean-12-en-28-ate. Structures were established on the basis of spectroscopic and chemical evidence, along with the comparison of the data reported in the literature.

Keywords: Siphoneugena densiflora, Myrtaceae, chemotaxonomy, hydrolysable tannin, pentacyclic triterpene

\section{Introduction}

The genus Siphoneugena comprises only eight species and belongs to Myrtaceae family. It is one of the specialized genera segregated from Eugenia by Berg. ${ }^{1}$ Siphoneugena densiflora Berg, commonly known as

*e-mail: marejor@uol.com.br
Uvatinga, occurs in montane grasslands ("campos rupestres"), deciduous forests (“cerradões") and gallery forests in Southern Goiás State, Distrito Federal, Minas Gerais and São Paulo States of Brazil. ${ }^{1}$ That species is the first one of the genus which has been chemically studied. Generic delimitation is a severe problem in Eugeniinae subtribe, ${ }^{1}$ and chemosystematics must be used to refine, reinforce or revise taxonomic systems based on 
morphological and anatomical characters. This paper deals with the results of a phytochemical survey of extracts from $S$. densiflora, reporting the isolation and structural elucidation of six new secondary metabolites (1-6), together with twenty one known compounds (7-27). In addition, some isolated compounds are being brought into focus as useful chemotaxonomic features to differentiate the investigated genus from Eugenia.

\section{Results and Discussion}

From the ethyl acetate residue of methanolic extract of root bark from $S$. densiflora were characterized five novel hydrolysable tannins named ellagic acid 4- $O-\alpha$ L-2"-O-acetylrhamnopyranoside (1), ellagic acid 4-O$\alpha$-L-3"-O-acetylrhamnopyranoside (2), siphoneugenin (3), 3,4'-di- $O$-methylellagic acid 4-O- $\beta$-D-6" $O$ acetylglucopyranoside (4), and 3,4'-di- $O$-methylellagic acid 4-O- $\beta$-D-3", 6"-di- $O$-acetylglucopyranoside (5), along with the identification of the well known substances ellagic acid 4-O- $\alpha$-L-4"' $O$-acetylrhamnopyranoside (7), ${ }^{2}$ ellagic acid 4- $O-\alpha$-L-rhamnopyranoside or eschweilenol C (8), ${ }^{3}$ gallic acid $(\mathbf{9}),{ }^{4}$ syringic acid (10), ${ }^{5}$ sitosterol (11), ${ }^{6}$ sitosterol 3-O- $\beta$-D-glucopyranoside or daucosterol (12), ${ }^{7}$ ellagic acid (13), ${ }^{8}$ rhamnose (14), casuarinin (15) $)^{9}$ and castalagin (16). ${ }^{10}$ The fractionation of the ethyl acetate residue of the methanolic extract of leaves led to the isolation of the new triterpenoid 28- $\beta$-D-glucopyranosyl-6 $\beta$-hydroxymaslinate or $\beta$-D-glucopyranosyl- $2 \alpha, 3 \beta, 6 \beta$-trihydroxyolean-12-en-28-ate (6), as well as six known compounds: syringic acid (10), ${ }^{5}$ quercetin (17), quercitrin (18), quercetin-3-O- $\alpha$-L-arabinopyranoside or guiajaverin (19), quercetin-3-O- $\beta$-D-xylopyranoside or reynoutrin (20), ${ }^{11}$ and chebuloside II (21). ${ }^{12}$ The dichloromethane residue of the methanolic extract of leaves led to the identification of six known triterpenes: $\alpha$-amyrin (22), $\beta$-amyrin (23), lupeol (24), ${ }^{13}$ terminolic (25), ${ }^{14}$ madecassic (26) and asiatic (27) ${ }^{15}$ acids. The structures of the compounds were determined by spectrometric methods, primarily from the ${ }^{1} \mathrm{H},{ }^{13} \mathrm{C}, 1 \mathrm{D}$ and $2 \mathrm{D}$ NMR and ESI-MS techniques and comparison of the data with those reported in the literature.

The small amount and the difficulty of separation, led us to characterize compounds $\mathbf{1 ,} \mathbf{2}$ and $\mathbf{7}$ as a mixture. The integration of the proton signals at $\delta 7.81(\mathbf{1}), \delta 7.79$ (2) and $\delta 7.78$ (7) in the ${ }^{1} \mathrm{H}$ NMR spectrum beside cross peaks of these protons with carbon at $\delta 149.2(\mathrm{C}-4, \mathbf{1}, 2$ and 7), a ${ }^{2} J(C, H)$ correlation observed in the HMBC spectrum (Table 2), and with carbons at $\delta 110.7$ or 110.3 $(\mathrm{C}-5,1,2$ and 7$)$, a $J(\mathrm{C}, \mathrm{H})$ correlation observed in the HSQC spectrum, suggested that the ratio of these compounds in the mixture was about $1: 1: 1$. Their ${ }^{1} \mathrm{H}$ NMR spectrum (Table 1) was very similar to that of $\mathbf{8}$, except<smiles>O=c1oc2c(O)c(O)cc3c(=O)oc4c(O)c(O)cc1c4c23</smiles>

13

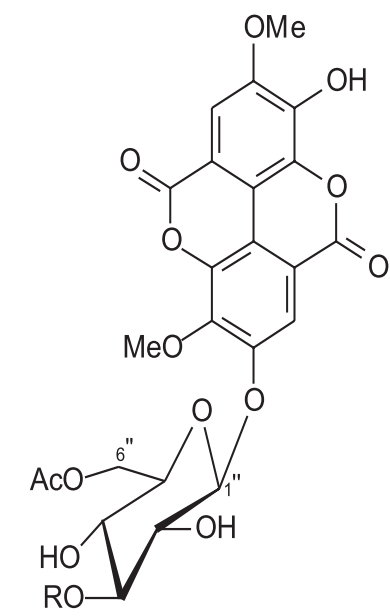

$\mathrm{R}$

$4 \mathrm{H}$

5 Ac

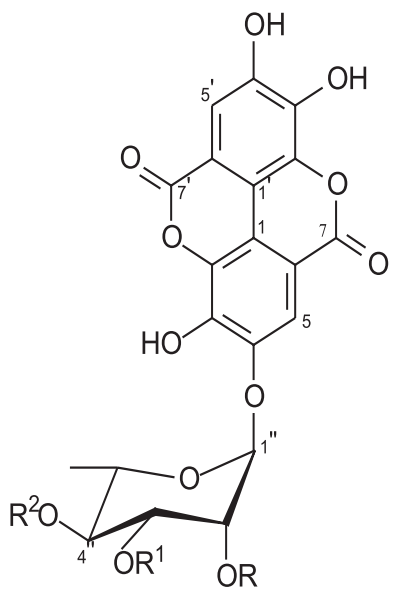

R $\quad R^{1} \quad R^{2}$

$\begin{array}{llll}1 & \text { Ac } & H & H \\ 2 & H & \text { Ac } & H \\ 7 & H & H & \text { Ac } \\ 8 & H & H & H\end{array}$




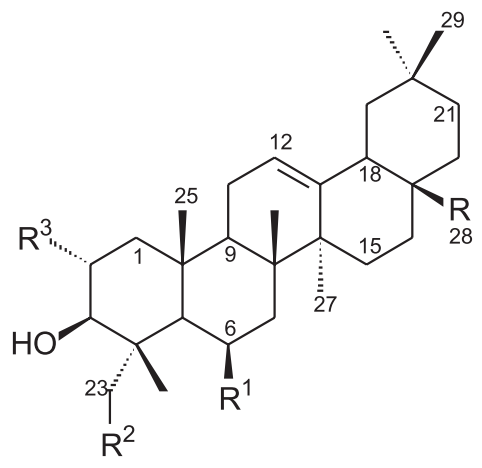

$\begin{array}{llll}R & R^{1} & R^{2} & R^{3}\end{array}$

6 coOGlu $\mathrm{OH} \quad \mathrm{H} \quad \mathrm{OH}$

21 cOOGlu OH OH OH

$23 \mathrm{Me} \quad \mathrm{H}$ H H

$25 \mathrm{COOH} \quad \mathrm{OH} \quad \mathrm{OH} \quad \mathrm{OH}$<smiles>[R]CC1(C)C(O)C([R])CC2(C)C1C([R])CC1(C)C3CCC4([R])CCCC(C)C4C3=CC[C@]12C</smiles>

Scheme 2 .<smiles>COc1cc2c(c(OC)c1OC)Oc1c(cc(C(=O)O)c(O)c1O)O2</smiles>

$3 a$<smiles>COc1cc2c(c(OC)c1OC)Oc1c(O)cc(C(=O)O)c(O)c1O2</smiles>

3

Scheme 3.<smiles>[R]c1c(-c2ccc(O)c(O)c2)oc2cc(O)cc(O)c2c1=O</smiles>

$17 \mathrm{H}$

18 Rha

19 Ara

$20 \mathrm{Xyl}$

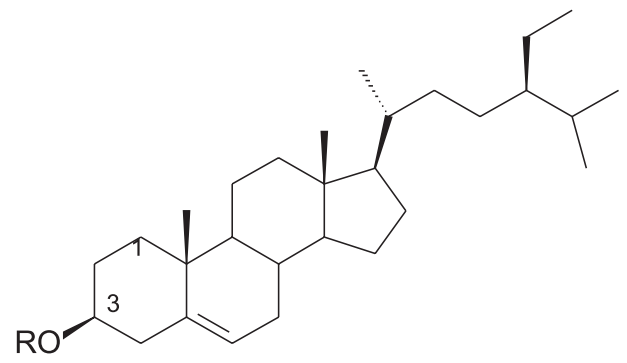
$\mathrm{R}$
$11 \mathrm{H}$
$12 \mathrm{Glu}$ 
<smiles>[R]Oc1cc(C(=O)O)cc([R])c1O</smiles>

$R$

$9 \mathrm{H}$

$10 \mathrm{Me}$

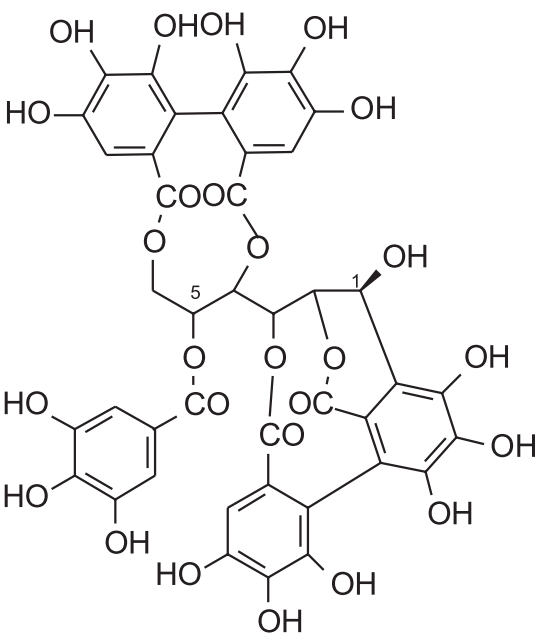

15<smiles>CC(=O)C1CCC2(C)CCC3C(CCC4C3(C)CCC3C(C)(C)C(O)CCC34C)C12</smiles>

24

Scheme 5.

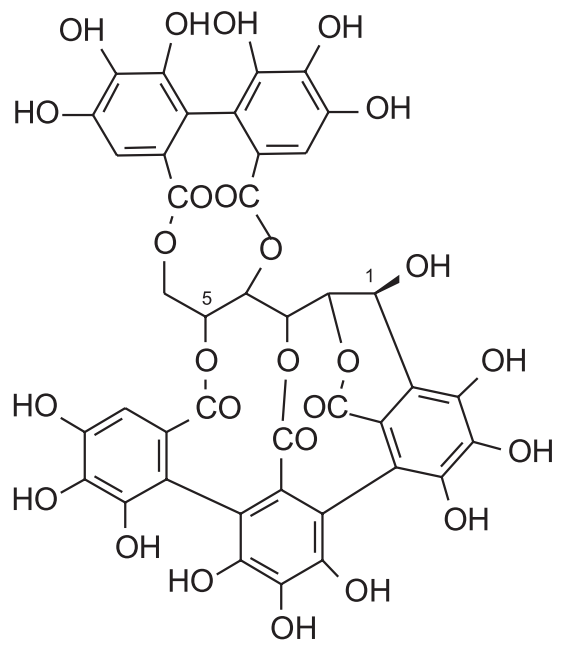

16

Scheme 6.

for the signals correspondent to acetyl groups. The position of acetyl groups was determined carefully by cross peak of the signals at $\delta 5.42(\mathrm{H}-2$ ", 1), $5.23(\mathrm{H}-3$ ", 2) and 5.03 (H-4", 7) with carbons at $\delta 74.1,75.7$ and 75.6 (C-2", C3" and C-4" of 1, 2 and 7, respectively, $J(\mathrm{C}, \mathrm{H}))$ and a ${ }^{3} J$ $(\mathrm{C}, \mathrm{H})$ correlation with the ester carbon at $\delta 173.2(\mathbf{1}, \mathbf{2}$ and 7). The chemical shift of ester carbon was confirmed by cross peak $\left({ }^{2} J(\mathrm{C}, \mathrm{H})\right.$ correlation) with methyl protons at $\delta 2.11(\mathbf{1}), 2.16(2)$ and 2.18 (7) in the HMBC spectrum. ${ }^{1} \mathrm{H}{ }^{13} \mathrm{C}$ long-range correlation from the anomeric protons at $\delta 5.56(\mathbf{1}), 5.55(2)$ and $5.54(7)$ to C-4 ( $\delta 149.2)$ of the ellagic acid moiety ascertained that the rhamnose residue was attached to $\mathrm{C}-4$ of the aglycone. Their molecular formula was determined to be $\mathrm{C}_{22} \mathrm{H}_{18} \mathrm{O}_{13}$ from the pseudo molecular ion peak at $\mathrm{m} / \mathrm{z} 489[\mathrm{M}-\mathrm{H}]^{-}$, the fragment ion peaks at $\mathrm{m} / z 447\left[\mathrm{M}-\mathrm{H}_{-} \mathrm{H}_{2} \mathrm{CCO}\right]^{-}$and at $\mathrm{m} / \mathrm{z} 301[\mathrm{M}-\mathrm{H}-$ $\mathrm{H}_{2} \mathrm{CCO}-$ rha $]^{-}$, observed in the ESI-MS negative ion mode.
Thus, the structure of $\mathbf{1}$ was assigned as ellagic acid 4-O$\alpha$-L-2"- $O$-acetylrhaminopyranoside; 2 as ellagic acid 4$O-\alpha$-L-3"- $O$-acetylrhaminopyranoside and 7 as ellagic acid 4- $O-\alpha$-L-4"- $O$-acetylrhaminopyranoside. ${ }^{2}$

Siphoneugenin (3) was isolated as a white powder. IR spectrum displayed characteristic absorptions for hydroxyl $\left(3386 \mathrm{~cm}^{-1}\right)$, methoxyl $\left(2925 \mathrm{~cm}^{-1}\right)$, acid carbonyl $\left(1705 \mathrm{~cm}^{-1}\right)$ and aromatic ring $(1613,1507$, $1425 \mathrm{~cm}^{-1}$ ) groups. ${ }^{1} \mathrm{H}$ NMR spectrum (Table 3) disclosed two singlets in the aromatic region at $\delta 7.12$ and 6.39; a doublet at $\delta 4.99(J 7.6 \mathrm{~Hz})$ and superimposable signals between $\delta$ 4.39-3.40 indicated the presence of a sugar moiety at $\beta$ configuration; two singlets at $\delta 3.72$ and 3.63 shown the presence of methoxyl groups. ${ }^{13} \mathrm{C}$ NMR spectrum (Table 3 ) revealed 20 signals. Carbon signal at $\delta 167.5$ confirmed the presence of acid carbonyl observed in IR spectrum. Carbon signals at $\delta$ 101.9, 76.7-64.7 
Table 1. ${ }^{1} \mathrm{H}$ NMR spectral data of compounds $1,2,4,5$ and 7

\begin{tabular}{|c|c|c|c|c|c|}
\hline \multirow[b]{2}{*}{${ }^{1} \mathrm{H}$} & \multicolumn{5}{|c|}{ Compound } \\
\hline & $\mathbf{1}^{\mathrm{a}}$ & $2^{\mathrm{a}}$ & $7^{\mathrm{a}}$ & $4^{c}$ & $5^{\mathrm{c}}$ \\
\hline 5 & $7.81(\mathrm{~s})^{\mathrm{b}}$ & $7.79(\mathrm{~s})^{\mathrm{b}}$ & $7.78(\mathrm{~s})^{\mathrm{b}}$ & $7.59(\mathrm{~s})$ & $7.59(\mathrm{~s})$ \\
\hline 5 & $7.47(\mathrm{~s})$ & $7.47(\mathrm{~s})$ & $7.47(\mathrm{~s})$ & $6.74(\mathrm{~s})$ & $7.15(\mathrm{~s})$ \\
\hline $1 "$ & $5.56(\mathrm{br} \mathrm{s})^{\mathrm{b}}$ & $5.55(\mathrm{br} \mathrm{s})^{\mathrm{b}}$ & $5.54(\mathrm{br} \mathrm{s})^{\mathrm{b}}$ & $4.94(\mathrm{~d}, 7.6)$ & $4.60(\mathrm{~d}, 7.6)$ \\
\hline $2 "$ & $5.42(\mathrm{dd}, 1.6,3.4)$ & $4.39(\mathrm{dd}, 1.6,3.2)$ & $4.39(\mathrm{dd}, 1.6,3.2)$ & * & * \\
\hline $3 "$ & $4.02(\mathrm{dd}, 3.4,9.5)$ & $5.23(\mathrm{dd}, 3.2,9.6)$ & $4.02(\mathrm{dd}, 3.2,9.5)$ & $*$ & $*$ \\
\hline $4 "$ & $3.49(\mathrm{t}, 9.5)$ & $3.70(t, 9.6)$ & $5.03(\mathrm{t}, 9.5)$ & $*$ & $*$ \\
\hline $5 "$ & $3.78(\mathrm{dd}, 9.5,6.3)$ & $3.78(\mathrm{dd}, 9.6,6.3)$ & $3.78(\mathrm{dd}, 9.5,6.3)$ & $*$ & $*$ \\
\hline $6 "$ & $1.15(\mathrm{~d}, 6.3)^{\mathrm{b}}$ & $1.32(\mathrm{~d}, 6.3)^{\mathrm{b}}$ & $1.12(\mathrm{~d}, 6.3)^{\mathrm{b}}$ & $4.46(\mathrm{dd}, 11.0,4.0)$ & $3.37(\mathrm{dd}, 12.0,5.0)$ \\
\hline$\underline{\mathrm{H}}_{3} \mathrm{CCO}$ & $2.11(\mathrm{~s})^{\mathrm{b}}$ & $2.16(\mathrm{~s})^{\mathrm{b}}$ & $2.18(\mathrm{~s})^{\mathrm{b}}$ & $2.05(\mathrm{~s})$ & $2.07(\mathrm{~s}) ; 2.05(\mathrm{~s})$ \\
\hline OMe-3 & & & & $3.48(\mathrm{~s})$ & $3.48(\mathrm{~s})$ \\
\hline OMe-4' & & & & $3.83(\mathrm{~s})$ & $3.83(\mathrm{~s})$ \\
\hline
\end{tabular}

${ }^{a}$ Recorded in $\mathrm{CD}_{3} \mathrm{OD}$, chemical shifts values are reported as $\delta$ from TMS at $400 \mathrm{MHz}$, signal multiplicity and coupling constants (Hz) are shown in parentheses; ${ }^{\mathrm{b}}$ Values are interchangeable within the same line; ${ }^{\mathrm{c}}$ Recorded in acetone- $d_{6}$ at $400 \mathrm{MHz}$; ${ }^{*}$ Signals overlapped.

Table 2. $\mathrm{HMBC}{ }^{1} \mathrm{H} \rightarrow{ }^{13} \mathrm{C}$ correlations for compounds $1,2,4,5$ and 7

\begin{tabular}{|c|c|c|c|c|c|}
\hline \multirow[b]{2}{*}{${ }^{1} \mathrm{H}$} & \multicolumn{5}{|c|}{ Compound } \\
\hline & $\mathbf{1}^{\mathrm{a}}$ & $2^{\mathrm{a}}$ & $7^{\text {a }}$ & $4^{b}$ & $5^{b}$ \\
\hline 5 & C-4; C-6; C-7 & C-4; C-6; C-7 & C-4; C-6; C-7 & C-3; C-6; C-7 & C-3; C-6; C-7 \\
\hline $5^{\prime}$ & C-4'; C-6'; C-7' & C-4'; C-6'; C-7' & C-4'; C-6'; C-7' & C-1'; C-3' & C-1'; C-3' \\
\hline $1 "$ & C-3”; C-4 & C-2”; C-4 & $\mathrm{C}-4$ & C-4 & C-4 \\
\hline $2 "$ & $\mathrm{C}-1 " ; \mathrm{H}_{3} \mathrm{CCO}$ & C-3" & C-3" & & \\
\hline $3 "$ & $\mathrm{C}-2 ”$ & $\mathrm{H}_{3} \mathrm{CCO}$ & C-2" & & $\mathrm{C}-2 " ; \mathrm{H}_{3} \mathrm{CCO}$ \\
\hline $4 "$ & C-3"; C-6" & & $\mathrm{H}_{3} \mathrm{C} \underline{\mathrm{CO}}$ & & \\
\hline \multicolumn{6}{|l|}{$5^{\prime \prime}$} \\
\hline $6 "$ & & C-4" & C-4" & $\mathrm{H}_{3} \mathrm{C} \underline{\mathrm{CO}}$ & $\mathrm{H}_{3} \mathrm{C} \underline{\mathrm{CO}}$ \\
\hline$\underline{\mathrm{H}}_{3} \mathrm{CCO}$ & $\mathrm{H}_{3} \mathrm{C} \underline{\mathrm{CO}}$ & $\mathrm{H}_{3} \mathrm{C} \underline{\mathrm{CO}}$ & $\mathrm{H}_{3} \mathrm{C} \underline{\mathrm{CO}}$ & $\mathrm{H}_{3} \mathrm{C} \underline{\mathrm{CO}}$ & $\mathrm{H}_{3} \mathrm{CCO}$ \\
\hline \multicolumn{6}{|l|}{ OMe-3 } \\
\hline OMe-4' & & & & C-4' & C-4' \\
\hline
\end{tabular}

${ }^{\text {a }}$ Recorded in $\mathrm{CD}_{3} \mathrm{OD}$ at $400 \mathrm{MHz}(\mathrm{J} 8.0 \mathrm{~Hz}) ;{ }^{\text {b }}$ Recorded in acetone- $d_{6}$ at $400 \mathrm{MHz}(\mathrm{J} 8.0 \mathrm{~Hz})$.

helped to determine the stereochemistry and nature of sugar moiety as $\beta$-D-glucopyranose. Signals at $\delta 56.3$ and 60.8 confirmed two methoxyl groups attached to one and di-ortho substituted carbon, respectively. The compound was found to have the composition $\mathrm{C}_{21} \mathrm{H}_{22} \mathrm{O}_{14}$ by analysis of its ${ }^{13} \mathrm{C}$ NMR spectrum and from the pseudo molecular ion peak at $\mathrm{m} / z 497[\mathrm{M}-\mathrm{H}]^{-}$, the fragment ion peaks at $m / z, 453\left[\mathrm{M}-\mathrm{H}-\mathrm{CO}_{2}\right]^{-}$and at $\mathrm{m} / z 335$ [M-H-glu] $^{-}$, observed in the ESI-MS negative ion mode. HMBC spectrum (Table 3) showed a cross peak between anomeric proton signal at $\delta 4.99$ and aromatic carbon at $\delta 154.9$ confirming the linkage site of the monosaccharide at C-4' of the aglycone. The results obtained from NOE difference spectra of $\mathbf{3}$ performed by irradiation at $\delta 3.72$ revealing enhancement at $\delta 6.39$ (H-6') and absence of NOE by irradiation at $\delta 3.63$ were used to locate the methoxyl groups at 5' and 3' positions, respectively. ${ }^{1} \mathrm{H}^{13} \mathrm{C} \mathrm{HSQC}$ correlation of aromatic proton signal at $\delta 6.39$ (H-6') with a shielded carbon signal at $\delta$ 95.5 and cross peaks of this proton signal with two aromatic carbons in the HMBC spectrum (C-4' and C2', Table 3) suggested the presence of a dibenzo-1',4dioxin structure. ${ }^{3,16}$ All of the above mentioned data and symmetry of the molecule suggested several possible isomers. We proposed a biosynthetic route for formation of $\mathbf{3}$ through phenolic oxidative coupling between gallic and syringic acid units, followed by an oxidation of aromatic ring, ${ }^{17}$ but this could not be assumed to be the correct structure. A strategy was considered to solve the problem of the structural assignment, between $\mathbf{3}$ and $\mathbf{3 a}$. UV spectral shift reagents were used to find the positions of hydroxyl groups. When the spectrum was run in methanol containing aluminum chloride, there was a bathochromic shift of $14 \mathrm{~nm}$, indicating the presence of a quelate hydroxyl group, ${ }^{18}$ but this result was not sufficient to distinguish between the two proposed structures. Nevertheless, addition of boric acid and sodium acetate caused no shift change in UV absorptions, confirming that no ortho-dihydroxyphenol system (cathecol) was present at the molecule. Accordingly the 
Table 3. ${ }^{13} \mathrm{C}$ NMR, ${ }^{1} \mathrm{H}$ NMR and HMBC spectral data for $3^{a}$

\begin{tabular}{|c|c|c|c|}
\hline Position & $\delta{ }^{13} \mathrm{C}$ & $\delta^{1} \mathrm{H}^{\mathrm{b}}$ & $\mathrm{HMBC}{ }^{1} \mathrm{H} \rightarrow{ }^{13} \mathrm{C}$ \\
\hline 1 & 120.9 & & \\
\hline 2 & 109.8 & $7.12(\mathrm{~s})$ & C-1; C-3; C-6; C-7 \\
\hline 3 & 145.9 & & \\
\hline 4 & nd & & \\
\hline 5 & 137.4 & & \\
\hline 6 & 139.1 & & \\
\hline 7 & 167.5 & & \\
\hline $1^{\prime}$ & 128.6 & & \\
\hline $2^{\prime}$ & 133.9 & & \\
\hline $3^{\prime}$ & 138.1 & & \\
\hline $4^{\prime}$ & 154.9 & & \\
\hline 5, & 148.4 & & \\
\hline $6^{\prime}$ & 95.5 & $6.39(\mathrm{~s})$ & C-2'; C-4' \\
\hline OMe-3' & 60.8 & 3.63 (s) & C-2' \\
\hline OMe-5' & 56.3 & $3.72(\mathrm{~s})$ & C-4' \\
\hline $1 "$ & 101.9 & $4.99(\mathrm{~d}, 7.6)$ & C-4' \\
\hline 2" & 74.7 & $3.86(\mathrm{~m})$ & \\
\hline $3 "$ & 76.7 & $3.57(\mathrm{~m})$ & C-2"; C-4" \\
\hline $4 "$ & 70.8 & $3.55(\mathrm{~m})$ & C-3" \\
\hline $5 "$ & 73.9 & $3.49(\mathrm{~m})$ & C-1"; C-3" \\
\hline \multirow[t]{2}{*}{$6 "$} & 64.7 & $4.39(\mathrm{dd}, 5.0,12.0)$ & \\
\hline & & $4.64(\mathrm{dd}, 1.8,12.0)$ & \\
\hline
\end{tabular}

${ }^{a}$ Spectra recorded in acetone- $d_{6} ; 400 \mathrm{MHz}$ for ${ }^{1} \mathrm{H}$ NMR and HMBC $(J$ $8.0 \mathrm{~Hz}) ; 100 \mathrm{MHz}$ for ${ }^{13} \mathrm{C}$ NMR; ${ }^{\mathrm{b}}$ Signal multiplicity and coupling constants $(\mathrm{Hz})$ are shown in parentheses; nd = signal not detected.

spectroscopic and chemical evidence obtained, the structure of siphoneugenin was deduced to being that shown in formula 3 .

Compounds $\mathbf{4}$ and $\mathbf{5}$ have also been characterized as a mixture. Their ${ }^{1} \mathrm{H}$ NMR spectrum (Table 1) was closely related to that of $\mathbf{1}$, in particular the signals arising from aromatic rings and acetyl groups. However, significant differences were revealed as the presence of two sugar anomeric doublets at $\delta 4.94$ and $4.60(J$ $7.6 \mathrm{~Hz}$ ), the signals at $\delta 3.83$ and $\delta 3.48$ indicating two methoxyl groups, the signals relative to a $\mathrm{CH}_{2} \mathrm{OAc}$ group, and the lack of the signal relative to the methyl group linked to C-5" of compound 1. Furthermore, the negative ESI-MS spectrum displayed two $[\mathrm{M}-\mathrm{H}]^{-}$peaks at $\mathrm{m} / \mathrm{z} 533$ and 575, respectively, whose are 44 and 86 $\mathrm{u}$ larger than that of compound $\mathbf{1}$. These data suggested that compound $\mathbf{4}$ and $\mathbf{5}$ had a glucose moiety at $\beta$ configuration, being compound $\mathbf{5}$ with an additional acetyl group. The location of acetyl groups was determined at the same way for compound $\mathbf{1}$. The results acquired from NOE difference spectra of $\mathbf{4}$ and $\mathbf{5}$ carried out by irradiation at $\delta 3.83$ showing signal enhancement at $\delta 6.74\left(\mathrm{H}-5^{\prime}\right)$ and absence of NOE by irradiation of signal at $\delta 3.48$ were used to locate the methoxyl groups at C-4' and C-3, respectively. In addition, ${ }^{1} \mathrm{H}^{13} \mathrm{C}$ HSQC correlations of signals at $\delta 3.83$ and 3.48 with carbons at $\delta 56.7$ and 61.3 , respectively, along with HMBC correlations (Table 2) between proton signal at $\delta 3.83$ and carbon at $\delta 148.2\left(\mathrm{C}^{\prime} 4^{\prime}\right)$, proton signal at $\delta 6.74$ $\left(\mathrm{H}-5^{\prime}\right)$ and carbon at $\delta 137.4\left(\mathrm{C}^{\prime} 3^{\prime}\right)$; and proton signal at $\delta 7.59(\mathrm{H}-5)$ and carbons at $\delta 141.0(\mathrm{C}-3)$ and 162.2 (C-7) confirmed the linkages of methoxyl groups at carbons C-3 and C-4' of the aglycone. Long-range correlation between anomeric proton at $\delta 4.94$ with $\mathrm{C}$ 4 at $\delta 154.1$ revealed the bonding site of the sugar. Thus, compound 4 was characterized as 3,4'-di- $O$-methylellagic acid 4- $O-\beta$-D-6"- $O$-acetylglucopyranoside and compound 5 as 3,4'-di- $O$-methylellagic acid $4-O-\beta$-D3", 6"-di- $O$-acetylglucopyranoside.

Compound 6 was obtained as a white amorphous powder. The ${ }^{1} \mathrm{H}$ NMR, ${ }^{1} \mathrm{H}^{13} \mathrm{C}$ HSQC and ${ }^{13} \mathrm{C}$ (DEPT) NMR spectra (Table 4) indicated the presence of seven tertiary methyl groups, an olefinic proton $\mathrm{H}-12$ coupled with a carbon at $\delta 123.5$, a quaternary carbon at $\delta 143.9$ (C-13), and a $\beta-18$ proton at $\delta 3.19(\mathrm{dd}, 4.1$ and $13.2 \mathrm{~Hz})$, that are typical signals of an oleanene skeleton. Moreover, an anomeric proton signal at $\delta 6.28$, in addition with several signals between $\delta 4.01-4.45$, confirmed the presence of a hexose unit. The relative stereochemistry and nature of the sugar moiety were determined as $\beta$-D-glucopyranose on the basis of the characteristic $J_{1,2}$ coupling constant of its anomeric proton $(J 8.0 \mathrm{~Hz})$ and typical ${ }^{1} \mathrm{H}$ and ${ }^{13} \mathrm{C}$ NMR shifts. ${ }^{19}$ The ester linkage was located at C-28 with the $\delta$ shifted downfield from 180.1 (its aglycone) ${ }^{20}$ to 176.9, and C-1' anomeric carbon at $\delta$ 96.2. In addition, HMBC spectrum (Table 4) displayed a cross peak between C-28 and $\mathrm{H}-1$ ', confirming the linkage site of the monosaccharide at $\mathrm{C}-28 .{ }^{1} \mathrm{H}-{ }^{1} \mathrm{H}$ COSY (Table 4) couplings between proton signal at $\delta 2.30(\mathrm{H}-1 \mathrm{a})$ with $1.39(\mathrm{H}-1 \mathrm{~b})$ and $4.29(\mathrm{H}-2)$, respectively, and ${ }^{1} \mathrm{H}-{ }^{13} \mathrm{C}$ HSQC correlation of the carbon signal at $\delta 50.4$ with the proton signal at $\delta$ $2.30(\mathrm{H}-1 \mathrm{a})$ became possible the doubtless assignments for $\mathrm{H}-1 \mathrm{a}$ and $\mathrm{H}-1 \mathrm{~b}$, which are changed with $\mathrm{H} 19 \mathrm{a}$ and $\mathrm{H} 19 \mathrm{~b}$ in the literature. ${ }^{20}$ Furthermore, the negative ESIMS spectrum displayed a pseudo molecular ion at $\mathrm{m} / \mathrm{z}$ $649[\mathrm{M}-\mathrm{H}]^{-}$and a fragment ion peak at $\mathrm{m} / z 487[\mathrm{M}-\mathrm{H}-$ glu] $]^{-}$, and the molecular formula was determined as $\mathrm{C}_{36} \mathrm{H}_{58} \mathrm{O}_{10}$. Thus, compound 6 was assigned as $28-\beta$-Dglucopyranosyl-6 6 -hydroxymaslinate.

The occurrence of triterpenes in leaves of Myrtaceae is high and frequent, ${ }^{21}$ but terminolic (25) and madecassic (26) acids have only been recently reported in Syzygium, ${ }^{14}$ and compound $\mathbf{2 5}$ in Myrtus. ${ }^{22}$ Chebuloside II (21), a pentacyclic triterpene glucoside, has been previously isolated from Terminalia chebula (Combretaceae), ${ }^{12}$ but this is the first report of this compound from the family Myrtaceae. The glycosidic pattern of the found flavonols (17-20) is a simple one 
Table 4. ${ }^{13} \mathrm{C}$ (DEPT) NMR, ${ }^{1} \mathrm{H}$ NMR, HMBC and COSY spectral data for $\mathbf{6}^{\mathrm{a}}$

\begin{tabular}{|c|c|c|c|c|}
\hline POSITION & $\delta{ }^{13} \mathrm{C}$ (multiplicity) & $\delta^{1} \mathrm{H}^{\mathrm{b}}$ & $\operatorname{COSY}\left({ }^{1} \mathrm{Hx}-{ }^{1} \mathrm{H}\right)$ & $\mathrm{HMBC}{ }^{1} \mathrm{H} \rightarrow{ }^{13} \mathrm{C}$ \\
\hline \multirow[t]{2}{*}{1} & $50.4(\mathrm{t})$ & $2.30(\mathrm{~m})$ & $1.39 ; 4.29$ & C-2; C-3; C-5; C-10; C-25 \\
\hline & & $1.39(\mathrm{~m})$ & $2.30 ; 4.29$ & \\
\hline 2 & 69.2 (d) & $4.29(\mathrm{~m})$ & $2.30 ; 1.39 ; 3.43$ & \\
\hline 3 & $84.4(d)$ & $3.43(\mathrm{~d}, 9.4)$ & & C-2; C-4; C-24 \\
\hline 4 & $39.7(\mathrm{~s})$ & & & \\
\hline 5 & $56.9(\mathrm{~d})$ & $1.16(\mathrm{~m})$ & & \\
\hline 6 & $67.9(\mathrm{~d})$ & $4.39(\mathrm{~m})$ & & \\
\hline \multirow[t]{2}{*}{7} & $32.8(\mathrm{t})$ & $2.50(\mathrm{~m})$ & 1.23 & $\mathrm{C}-6$ \\
\hline & & $1.23(\mathrm{~m})$ & & \\
\hline 8 & $41.1(\mathrm{~s})$ & & & \\
\hline 9 & $49.1(\mathrm{~d})$ & & & \\
\hline 10 & $38.7(\mathrm{~s})$ & & & \\
\hline 11 & $24.4(t)$ & $2.14(\mathrm{t}, 3.8)$ & & \\
\hline 12 & $123.5(\mathrm{~d})$ & 5.52 (brs) & 2.14 & C-9; C-18 \\
\hline 13 & $143.9(\mathrm{~s})$ & & & \\
\hline 14 & $43.2(\mathrm{~s})$ & & & \\
\hline 15 & $28.6(\mathrm{t})$ & & & \\
\hline 16 & $24.4(t)$ & & & \\
\hline 17 & $47.4(\mathrm{~s})$ & & & \\
\hline 18 & $42.2(\mathrm{~d})$ & $3.19(\mathrm{dd}, 4.1,13.2)$ & $1.30 ; 1.78$ & C-12; C-13; C-17 \\
\hline \multirow[t]{2}{*}{19} & $46.7(t)$ & $1.30(\mathrm{~m})$ & $1.30 ; 3.19$ & \\
\hline & & $1.78(\mathrm{~m})$ & & \\
\hline 20 & $31.1(\mathrm{~s})$ & & & \\
\hline 21 & $34.4(\mathrm{t})$ & & & \\
\hline 22 & $28.6(\mathrm{t})$ & & & \\
\hline 23 & $29.0(\mathrm{q})$ & $1.46(\mathrm{~s})$ & & C-4; C-5 \\
\hline 24 & $19.6(\mathrm{q})$ & $1.79(\mathrm{~s})$ & & C-3; C- $4 ; C-5 ; C-23$ \\
\hline 25 & $19.2(q)$ & $1.72(\mathrm{~s})$ & & C-5; C-6; C-8;C-9 \\
\hline 26 & $19.6(q)$ & $1.70(\mathrm{~s})$ & & C-8; C-9; C-14 \\
\hline 27 & $26.5(\mathrm{q})$ & $1.25(\mathrm{~s})$ & & C-8; C-14 \\
\hline 28 & $176.9(\mathrm{~s})$ & & & \\
\hline 29 & $33.5(\mathrm{q})$ & $0.92(\mathrm{~s})$ & & $\mathrm{C}-30$ \\
\hline 30 & $24.1(\mathrm{q})$ & $0.88(\mathrm{~s})$ & & C-20; C-21 \\
\hline 1 ' & $96.2(d)$ & $6.28(\mathrm{~d}, 8.0)$ & 4.21 & C-28 \\
\hline 2 ' & $74.4(\mathrm{~d})$ & $4.21(\mathrm{t}, 8.3)$ & & $\mathrm{C}-1^{\prime} ; \mathrm{C}-3^{\prime}$ \\
\hline 3, & 78.9 (d) & $4.27(\mathrm{~m})$ & & C- 4 \\
\hline 4 & $71.5(\mathrm{~d})$ & $4.35(\mathrm{~d}, 9.4)$ & 4.01 & C-5 \\
\hline 5 & $79.5(\mathrm{~d})$ & $4.01(\mathrm{~m})$ & & \\
\hline \multirow[t]{2}{*}{$6^{\prime}$} & $62.5(\mathrm{t})$ & $4.45(\mathrm{dd}, 2.1,11.7)$ & & C-4' \\
\hline & & $4.39(\mathrm{~m})$ & & \\
\hline
\end{tabular}

${ }^{a}$ Spectra recorded in $\mathrm{C}_{5} \mathrm{D}_{5} \mathrm{~N} ; 400 \mathrm{MHz}$ for ${ }^{1} \mathrm{H}$ NMR, $\mathrm{HMBC}(\mathrm{J} 8.0 \mathrm{~Hz})$ and COSY; $50 \mathrm{MHz}$ for ${ }^{13} \mathrm{C} \mathrm{NMR}$; ${ }^{\mathrm{b}}$ Signal multiplicity and coupling constants $(\mathrm{Hz})$ are shown in parentheses.

and this is in keeping with the primitive morphological features of the family Myrtaceae. ${ }^{23}$ Tannin 7, initially found in Combretaceae, ${ }^{2}$ and tannin 8 , in Lecythidaceae,${ }^{3}$ are being reported for the first time in Myrtaceae together with compounds $\mathbf{1}$ and $\mathbf{2}$, although some methoxylated derivatives were reported for Eucalyptus globulus. ${ }^{24,25}$ Similar compounds to tannins 4 and 5 were found in Eucalyptus polyanthemos. ${ }^{26}$ According to Hillis and Yazaki, ${ }^{27}$ those ellagitannins have rarely been reported possibly to the difficulties in their isolation, purification and identification. In addition, some of them present poor solubility. All the tannins found in this phytochemical survey, except for $\mathbf{1 5}$ and 16, have not yet been reported to occur in
Eugenia and might be considered as chemical features for taxonomic purposes, justifying the segregation of Siphoneugena from that genus by Berg. ${ }^{1}$ Moreover, tannin 3 presents a new aglycone type for hydrolysable tannins and might also be taken into account as a valuable taxonomic character.

\section{Experimental}

\section{General experimental procedures}

IR spectra were measured on a Bomem MB-102 spectrophotometer in $\mathrm{KBr}$ pellets. UV spectra were obtained on a Varian Cary 500 Scan/UV-Vis-Nir 
spectrophotometer. Optical rotation was obtained on a Perkin Elmer 241 polarimeter. NMR spectra were recorded in acetone- $d_{6}, \mathrm{D}_{2} \mathrm{O}, \mathrm{CD}_{3} \mathrm{OD}$ or pyridine- $d_{5}$, using TMS as internal reference, employing a Bruker DRX-400 $\left({ }^{1} \mathrm{H}, 400\right.$ $\mathrm{MHz} ;{ }^{13} \mathrm{C}, 50$ or $100 \mathrm{MHz}$ ). Electrospray mass spectra were recorded on a Micromass Quattro LC-triple quadrupole. All compounds were analyzed in the negative ion mode. The mass conditions were optimized by direct injection. The source voltage was $3.90 \mathrm{kV}$; capillary voltage, 26-28 V; extractor, $4 \mathrm{~V}$; RF lens, $0.23 \mathrm{~V}$; capillary temperature, $130^{\circ} \mathrm{C}$; desolvation temperature, $300{ }^{\circ} \mathrm{C}$. HPLC system consisted of a Shimadzu LC-10AD pump, an SPD-10A UV-Vis detector, a CBM-10A interface and data acquisition performed on CLASS LC10 software. Column chromatography was performed with Kieselgel 60 (70-230 or 230-400 mesh, Merck), XAD7 (Aldrich Chemical Company Inc.) or Sephadex LH-20 (25-100 $\mu \mathrm{m}$, Pharmacie Fine Chemical Co. Ltd.). Spots were visualized under ultraviolet light of wavelength $254 \mathrm{~nm}$ and by spraying vanillin sulfuric acid solution and heating, or $\mathrm{FeCl}_{3}$ acid solution.

\section{Plant material}

Siphoneugena densiflora Berg (Myrtaceae) was collected in July, 2000, in Poços de Caldas city, Minas Gerais State, Brazil, and identified by Dr. Marcos Sobral. A voucher specimen is deposited at the Herbarium of the Botany Department (SPF), University of São Paulo, São Paulo State, Brazil.

\section{Extraction}

The air-dried powdered root bark $(0.4 \mathrm{~kg})$ and leaves $(0.9 \mathrm{~kg})$ of $S$. densiflora were extracted with hexane and $\mathrm{MeOH}$ through percolation processing at room temperature. Crude extracts were obtained after filtration and removal of the solvents under vacuum at $40{ }^{\circ} \mathrm{C}$. The methanolic extracts of root bark (RME, 73.2 g) and leaves (LME, 70.0 g) were dissolved in $\mathrm{H}_{2} \mathrm{O} / \mathrm{MeOH} 1: 1(\mathrm{v} / \mathrm{v})$ and fractionated through liquid-liquid partition using solvents of increasing polarity $\left(\mathrm{CH}_{2} \mathrm{Cl}_{2}, \mathrm{EtOAc}\right)$. The solvents were removed to yield the residues RMED (0.9 g), RMEAc (10.5 g), LMED (9.5 g) and LMEAc (14.6 g).

\section{Methanolic extract of root bark - isolation}

9.1 $\mathrm{g}$ of RMEAc were subjected to $\mathrm{CC}$ using silica gel $(38.0 \times 5.0 \mathrm{~cm}), \mathrm{CH}_{2} \mathrm{Cl}_{2} /$ EtOAc 7:3 as eluent and gradient elution. Sixty-five fractions of $150 \mathrm{~mL}$ were collected and pooled into 22 fractions. Fraction 6 (R6) was identified as 11 (white powder, $5.8 \mathrm{mg}$ ). Fraction 11 (R11, 317.0 $\mathrm{mg}$ ) was chromatographed over Sephadex LH-20 (52.0 x $3.0 \mathrm{~cm}$ ) using $\mathrm{MeOH}$ as eluent. Forty fractions of $30 \mathrm{~mL}$ were collected, afterwards the similar ones were joined to affording 15 fractions, being fraction six (R11f) identified as compound $\mathbf{1 0}$ (white powder, $14.7 \mathrm{mg}$ ). Fraction 12 (R12, $900.0 \mathrm{mg}$ ) was chromatographed over Sephadex LH-20 (66.0 x $2.0 \mathrm{~cm})$ using MeOH/acetone $8: 2$ as eluent. Twenty two fractions of $30 \mathrm{~mL}$ were collected and pooled into 11 fractions. Fraction 3 (R12d) was identified as $\mathbf{1 2}$ (white powder, $23.0 \mathrm{mg}$ ). Fraction 4 (R12e, $43.4 \mathrm{mg}$ ) was rechromatographed over Sephadex $\mathrm{LH}-20(60.0 \times 2.0 \mathrm{~cm})$ using $\mathrm{MeOH}$ as eluent. 13 fractions of $30 \mathrm{~mL}$ were collected and pooled into 8 fractions. Fraction three (R12e3) was identified as $\mathbf{1 4}$ (white powder, $8.7 \mathrm{mg}$ ) and fraction six (R12e6) as $\mathbf{3}$ (white powder, 1.9 $\mathrm{mg})$. Fraction 6 (R12f, $176.0 \mathrm{mg}$ ) was subjected to Sephadex LH-20 (60.0 x $2.0 \mathrm{~cm})$ using MeOH/acetone $7: 3$ as eluent. 14 fractions of $30 \mathrm{~mL}$ were collected and pooled into nine fractions. Fraction four (R12f4) was identified as 9 (white powder, $50.0 \mathrm{mg}$ ), fraction seven (R12f7) as compound 8 (pale yellow powder, $60.0 \mathrm{mg}$ ), and fraction nine (R12f9) as a mixture of compounds 4 and 5 (white powder, $3.0 \mathrm{mg}$ ). Fraction 18 (R18, 698.0 $\mathrm{mg}$ ) was subjected to XAD-7 $(67.0$ x $4.0 \mathrm{~cm})$ using $\mathrm{MeOH}$ as eluent. Ten fractions of $200 \mathrm{~mL}$ were collected and pooled into four. Fraction one (R18a) was further purified by R-HPLC (column ASAHIPAK GS-310 SHODEX, 10 x $300 \mathrm{~mm}$, mobile phase $\mathrm{MeOH}$, flow-rate $2 \mathrm{~mL} \mathrm{~min}^{-1} ; \lambda$ $330 \mathrm{~nm}$ ) to yield compound $\mathbf{1 3}$ (pale yellow powder, second peak, $109.4 \mathrm{mg}$ ) after one cycle of $74 \mathrm{~min}$. Twohundred and forty milligrams of fraction 19 (R19, 434.5 $\mathrm{mg}$ ) was chromatographed over Sephadex LH-20 (52.0 x $3.0 \mathrm{~cm}$ ) using $\mathrm{MeOH}$ as eluent. Thirty-one fractions of $30 \mathrm{~mL}$ were collected and pooled into eight fractions. Fraction eight (R19h, $127.6 \mathrm{mg}$ ) was rechromatographed over Sephadex LH-20 (52.0 x $3.0 \mathrm{~cm})$ using $\mathrm{MeOH}$ as eluent. Thirty-six fractions of $30 \mathrm{~mL}$ were collected and pooled into ten fractions. Fraction eight (R19h8) was identified as compound $\mathbf{1 6}$ (brown powder, $75.0 \mathrm{mg}$ ) and fraction ten (R19h10) as $\mathbf{1 5}$ (brown powder, $19.6 \mathrm{mg}$ ). The twentieth fraction (R20, $358.0 \mathrm{mg}$ ) was chromatographed on Sephadex LH-20 (31.0 x $3.0 \mathrm{~cm})$ using $\mathrm{MeOH}$ as eluent. Twenty-four fractions of $30 \mathrm{~mL}$ were collected and pooled into 8 fractions. The first fraction (R20A, $74.0 \mathrm{mg}$ ) was further purified by reversed-phase HPLC (column Hypersil ODS/C18, 10 x 300 mm; mobile phase $70 \% \mathrm{MeOH}$ aqueous solution; flow-rate $2 \mathrm{~mL}$ $\left.\min ^{-1} ; \lambda 300 \mathrm{~nm}\right)$. The peak with retention time of $20 \mathrm{~min}$ rendered an unseparated mixture of $\mathbf{1 , 2}$ and $\mathbf{7}$ (pale yellow powder, $8.2 \mathrm{mg}$ ). 
Methanolic extract of leaves - isolation

$4.7 \mathrm{~g}$ of LMEAc were chromatographed on silica gel 60 column $(30.0 \times 5.0 \mathrm{~cm})$ using step gradient from acetone/ethyl acetate 95:5 to methanol. Forty-seven fractions of $150 \mathrm{~mL}$ were collected and pooled into 15 fractions. The second fraction (L2, $96.4 \mathrm{mg}$ ) was submitted to CC using Sephadex LH-20 (100.0 x 2.5 $\mathrm{cm})$ and $\mathrm{MeOH}$ as eluent. Twenty-four fractions of 30 $\mathrm{mL}$ were collected and pooled into 10 fractions. Fraction five (L2e) was identified as compound $\mathbf{1 0}$ (white powder, $57.3 \mathrm{mg}$ ) and fraction ten (L2j) as $\mathbf{1 7}$ (yellow powder, $4.0 \mathrm{mg}$ ). The fifth fraction ( $\mathrm{L} 5,236.0 \mathrm{mg}$ ) was submitted to $\mathrm{CC}$ using Sephadex LH-20 (38.0 x $3.0 \mathrm{~cm})$ and $\mathrm{MeOH}$ as eluent. Seventeen fractions of $30 \mathrm{~mL}$ were collected and pooled into 8 fractions. Fraction two (L5b) was identified as compound 6 (white powder, $60.0 \mathrm{mg}$ ), fraction five (L5e) as the flavonoid $\mathbf{1 8}$ (yellow powder, $8.0 \mathrm{mg}$ ) and fraction six (L5f) as a mixture of $\mathbf{1 9}$ and $\mathbf{2 0}$ (yellow powder, $13.3 \mathrm{mg}$ ). The sixth fraction (L6, 784.0 $\mathrm{mg}$ ) was chromatographed over Sephadex LH-20 (100.0 x $2.5 \mathrm{~cm}$ ) using $\mathrm{MeOH}$ as eluent. Twenty-five fractions of $30 \mathrm{~mL}$ were collected and pooled into eight fractions. Fraction two (L6b) was identified as compound $\mathbf{2 1}$ (white powder, $61.0 \mathrm{mg}$ ).

$9.5 \mathrm{~g}$ of LMED was chromatographed over a mixture of silica gel (230-400 mesh) and florisil ${ }^{\circledR}(9: 1 \mathrm{~m} / \mathrm{m} ; 30.0$ x $5.5 \mathrm{~cm}$ ) using hexane/MeOH 95:5 as eluent and gradient elution. Sixty-five fractions of $150 \mathrm{~mL}$ were collected and pooled into 17 fractions. Fraction $7(\mathrm{Lg}, 381.8 \mathrm{mg})$ was rechromatographed over silica gel (230-400 mesh; $25.0 \mathrm{x}$ $3.0 \mathrm{~cm}$ ) using $\mathrm{CH}_{2} \mathrm{Cl}_{2}$ /acetone 1:1 as eluent and gradient elution. Thirty fractions of $100 \mathrm{~mL}$ were collected and pooled into 18 fractions. Fraction seven $(\operatorname{Lg} 7)$ was identified as a mixture of compounds $\mathbf{2 2 , 2 3}$ and $\mathbf{2 4}$ (white amorphous powder, $32.5 \mathrm{mg}$ ). Fraction $12(\mathrm{Lm}, 1.5 \mathrm{~g}$ ) was rechromatographed over silica gel (230-400 mesh; $61.0 \times 2.0 \mathrm{~cm}$ ) using gradient elution from $\mathrm{CH}_{2} \mathrm{Cl}_{2} /$ hexane 1:1 to acetone/MeOH 1:1. Sixty fractions of $150 \mathrm{~mL}$ were collected and pooled into 13 fractions. Fraction nine (Lm9, $219.0 \mathrm{mg}$ ) was subjected to CC over Sephadex LH-20 $(124.0 \times 2.5 \mathrm{~cm})$ using $\mathrm{MeOH}$ as eluent. Thirty fractions of $30 \mathrm{~mL}$ were collected and pooled into seven fractions. Fraction five (Lm95, $44.0 \mathrm{mg}$ ) was chromatographed over a mixture of silica gel and florisil ${ }^{\circledR}(9: 1 \mathrm{~m} / \mathrm{m} ; 30.0 \times 5.5$ $\mathrm{cm}$ ) using hexane/ EtOAc 1:1 as eluent and gradient elution. Twenty-five fractions of $30 \mathrm{~mL}$ were collected and pooled into six fractions. Fraction six (Lm956) was identified as a mixture of compounds $\mathbf{2 5 , 2 6}$ and $\mathbf{2 7}$ (white amorphous powder, $21.4 \mathrm{mg}$ ).
Compounds 1, 2 and 7 as a mixture

Pale yellow powder; $\mathrm{UV}(\mathrm{MeOH}) \lambda_{\max } / \mathrm{nm}(\log \varepsilon): 258$ (4.52), 352 (4.02); ESI-MS m/z (rel. int.): 489 [M-H] ${ }^{-}(40)$, 447 [M-H-H $\left._{2} \mathrm{CCO}\right]^{-}$(100), 301 [M-H- $\left.{ }_{2} \mathrm{CCO}-\mathrm{rha}\right]^{-}$(5); ${ }^{1} \mathrm{H}$ NMR $\left(\mathrm{CD}_{3} \mathrm{OD}, 400 \mathrm{MHz}\right)$ : see Table 1; HMBC ( $\mathrm{CD}_{3} \mathrm{OD}, 400 \mathrm{MHz}$ ): see Table 2;

${ }^{13} \mathrm{C}$ NMR $\left(\mathrm{CD}_{3} \mathrm{OD}, 100 \mathrm{MHz}\right) \delta: 173.2\left(\mathrm{C}, \mathrm{H}_{3} \mathrm{CCOO}\right)$, 162.5, 162.6 (C, C-7, 7'), 150.9, 149.2 (C, C-4, 4'), 138.9, 138.3 (C, C-2, 2'), 117.1, 114.7, 114.6, 114.1 (C, C-6, 6'), 110.7, 110.3 (CH, C-5, 5'), 107.4, 105.3 (C, C-1, 1'), 101.5, 101.3, 101.2 (CH, C-1"), 75.7 (CH, C-3" of 2), 75.6 (CH, C-4" of 7), $74.1(\mathrm{CH}, \mathrm{C}-2$ " of 1), 72.0, 72.3 (CH, C-3"), 71.4, 71.1 (CH, C-4"), 70.2 (CH, C-5"), 69.7, 68.9 (CH, C-2"), 21.3, 21.2 (CH3, $\left.\mathrm{H}_{3} \mathrm{CCOO}\right), 18.2,17.9$ (CH3, C-6").

\section{Compound 3}

White powder; UV $(\mathrm{MeOH}) \lambda_{\text {max }} / \mathrm{nm}(\log \varepsilon): 276$ (4.22), 356 (3.33); $\mathrm{UV}\left(+\mathrm{AlCl}_{3}\right) \lambda_{\max } / \mathrm{nm}(\log \varepsilon): 265$ (4.18), 297 (4.09), 370 (3.33); UV ( $\left.\mathrm{NaOAc}+\mathrm{H}_{3} \mathrm{BO}_{3}\right) \lambda_{\max } / \mathrm{nm}$ (log $\varepsilon$ ): 270 (4.13), $293 \mathrm{sh}, 352$ (3.45); IR (KBr) $v_{\max }$ / $\mathrm{cm}^{-1}: 3386,2925,1705,1613,1507,1425,1344,1225$, 1071, 1022, 764; ESI-MS m/z (rel. int.): 497 [M-H] ${ }^{-}(100)$, 453 [M-H-CO $]^{-}(5), 335$ [M-H-glu] ${ }^{-}(10) ;{ }^{1} \mathrm{H}$ NMR and HMBC (acetone- $d_{6}, 400 \mathrm{MHz}$ ): see Table $3 ;{ }^{13} \mathrm{C}$ NMR (acetone- $\mathrm{d}_{6}, 100 \mathrm{MHz}$ ): see Table 3.

\section{Compounds 4 and 5 as a mixture}

White powder; ESI-MS $m / z$ (rel. int.): 575 [M-H] $]^{-}(50)$, $533[\mathrm{M}-\mathrm{H}]^{-}(100) ;{ }^{1} \mathrm{H}$ NMR (acetone- $d_{6}, 400 \mathrm{MHz}$ ): see Table 1; HMBC (acetone- $d_{6}$, $400 \mathrm{MHz}$ ): see Table $2 ;{ }^{13} \mathrm{C}$ NMR (acetone- $\left.d_{6}, 100 \mathrm{MHz}\right): \delta 173.1$ (C, $\left.\mathrm{H}_{3} \mathrm{C} \underline{\mathrm{COO}}\right), 162.2$ (C, C-7, 7'), 154.1 (C, C-4), 148.2 (C, C-4'), 141.0 (C, C3), 137.4 (C, C-3'), 110.1, 109.9 (CH, C-5, 5'), 107.9, 109.5 (CH, C-1, 1'), 100.2, 98.8 (CH, C-1"), 79.8, 79.6 (CH, C6"), 81.7 (CH, C-3" of 5), $76.3(\mathrm{CH}, \mathrm{C}-3$ " of 4), $75.0(\mathrm{CH}$, C-2"), 70.4, 70.2 (CH, C-4"), 61.3 (CH3, OMe-3), 56.7 (CH3, OMe-4'), 21.1, 20.9 (CH3, $\left.\mathrm{H}_{3} \mathrm{CCOO}\right)$.

\section{Compound 6}

White amorphous powder; ESI/MS $m / z$ (rel. int.): 649 [M-H] $]^{-}(100), 487$ [M-H-glu] $]^{-}$(70). IR (KBr) $v_{\max } / \mathrm{cm}^{-1}$ : 3389, 2941, 2880, 1734, 1646, 1462, 1378, 1069, 1028; mp $144-147^{\circ} \mathrm{C} ;[\alpha]_{\mathrm{D}}{ }^{25}+5.09^{\circ}(c \mathrm{c} 0.005, \mathrm{MeOH})$; ${ }^{1} \mathrm{HNMR}$, COSY and HMBC (400 MHz, $\left.\mathrm{C}_{5} \mathrm{D}_{5} \mathrm{~N}\right)$ : see Table $4 ;{ }^{13} \mathrm{C}$ (DEPT) NMR (50 MHz, $\left.\mathrm{C}_{5} \mathrm{D}_{5} \mathrm{~N}\right)$ : see Table 4. 


\section{Acknowledgments}

The authors are grateful to Dr. Marcos Sobral for identifying botanical material, and ALCOA for facilitating plant collecting. This research was supported by CAPES and CNPq.

\section{References}

1. Proença, C.; Edinb. J. Bot. 1990, 47, 239.

2. Asami, Y.; Ogura, T.; Otake, N.; Nishimura, T.; Xinsheng, Y.; Sakurai, T.; Nagasawa, H.; Sakuda, S.; Tatsuta, K.; J. Nat. Prod. 2003, 66, 729.

3. Yang, S.; Zhou, B.; Wisse, J. H.; Evans, R.; Werff, H.; Miller, J. S.; Kingston, D. G. I.; J. Nat. Prod. 1998, 61, 901.

4. Tian, G.; Zhang, T.; Yang, F.; Ito, Y.; J. Chromatogr., A 2000 , 886, 309.

5. Gerothanassis, I. P.; Exarchou, V.; Lagouri, V.; Troganis, A.; Tsimidou, M.; Boskou, D.; J. Agric. Food Chem. 1998, 46, 4185.

6. Furuya, T.; Orihara, Y.; Hayashi, C.; Phytochemistry 1987, 26, 715.

7. Tandom, J. S.; Shukla, Y.; Thakur, R.; Phytochemistry 1990, 29, 2957.

8. Nawwar, M. A. M.; Hussein, S. A. M.; Merfort, I.; Phytochemistry 1994, 36, 793.

9. Okuda, T.; Yoshida, T.; Ashida, M.; Yazaki, K.; J. Chem. Soc., Perkin Trans. I 1983, 1765.

10. Vivas, N.; Laguerre, M.; Glories, Y.; Bourgeois, G.; Vitry, C.; Phytochemistry 1995, 39, 1193.

11. Agrawal, P. K. ed.; Carbon-13 NMR of Flavonoids, Elsevier: Amsterdan, 1989.

12. Kundu, A. P.; Mahato, S. B.; Phytochemistry 1993, 32, 999.
13. Mahato, S. B.; Kundu, A. P.; Phytochemistry 1994, 37, 1517.

14. Djoukeng, J. D.; Abou-Mansour, E.; Tabacchi, R.; Tapondjou, A. L.; Bouda, H.; Lontsi, D.; J. Ethnopharmacol. 2005, 101, 283.

15. Inamdar, P. K.; Yeole, R. D.; Ghogare, A. B.; Souza, N. J.; J. Chromatogr., A 1996, 742, 127.

16. Tanaka, T.; Orii, Y.; Nonaka, G.; Nishioka, I.; Kouno, I.; Phytochemistry 1996, 43, 1345.

17. Dewick, P. M.; Medicinal Natural Products: A Biosynthetic Approach, John Wiley \& Sons: New York, 1997.

18. Voirin, B.; Phytochemistry 1983, 22, 2107.

19. Arramon, G.; Saucier, C.; Colombani, D.; Glories, J.; Phytochem. Anal. 2002, 13, 305; Garcez, F. R.; Garcez, W. S.; Miguel, D. L. S.; Serea, A. A. T.; Prado, F. C.; J. Braz. Chem. Soc. 2003, 14, 461.

20. Zucaro, Y. L.; Compagnone, R. S.; Hess, S. C.; Delle Monache, F.; J. Braz. Chem. Soc. 2000, 11, 242.

21. Judd, W. S.; Campbell, C. S.; Kellogg, E. A.; Stevens, P. F.; Plant Systematics: A Phylogenetic Approach, $2^{\text {nd }}$ ed.; Sinauer Associates Inc.: Massachussets, 2001.

22. Erlacin, S.; Erciyas, E.; Doga Bilim Dergisi 1984, 8, 31 (CA 100:171.620).

23. Haron, N. W.; Moore, D. M.; Harborne, J. B.; Biochem. Syst. Ecol. 1992, 20, 266.

24. Kim, J.; Lee, I.; Yun, B.; Chung, S.; Shim, G.; Koshino, H.; Yoo I.; Phytochemistry 2001, 57, 587.

25. Yazaki, Y.; Hillis, W. E.; Phytochemistry 1976, 15, 1180.

26. Hillis, W. E.; Yazaki, Y.; Phytochemistry 1973, 12, 2963.

27. Hillis, W. E.; Yazaki, Y.; Phytochemistry 1973, 12, 2969.

Received: May 12, 2005

Published on the web: February 13, 2006

FAPESP helped in meeting the publication costs of this article. 